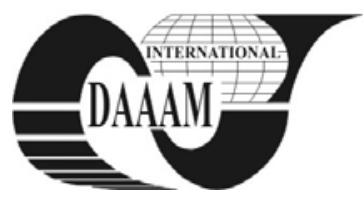

Annals of DAAAM for 2011 \& Proceedings of the 22nd International DAAAM Symposium, Volume 22, No. 1, ISSN $1726-9679$ ISBN 978-3-901509-83-4, Editor B. Katalinic, Published by DAAAM International, Vienna, Austria, EU, 2011 Make Harmony between Technology and Nature, and Your Mind will Fly Free as a Bird Annals \& Proceedings of DAAAM International 2011

\title{
MARTENS MICRO INDENTANTION STUDY OF NI GALVANIC DEPOSITION
}

\author{
SEVERIN, T[raian] - L[ucian]; GUTT, S[onia]; GUTT, G[heorghe]; POROCH - SERITAN, M[aria] \& STROE, \\ S[ilviu] - G[abriel]
}

\begin{abstract}
The purpose of this study was to investigate the influence of process parameters (current density, temperature and $\mathrm{pH}$ ) on the mechanical properties of galvanic deposition of nickel with Martens hardness test. Analyzing samples obtained by galvanic deposition process using Martens hardness we could show that there are significant differences between the technological parameters of the deposits made and we could find related to the deposition parameters in order to have a galvanic deposition expected outcomes. In the paper are presented in comparison parameters can be obtained by Martens hardness, such as hardness layer, elasticity modulus $E_{I T}$, mechanical work of deformation and the ratio of elastic deformation energy and the plastic.
\end{abstract}

Key words: nickel, electrodeposition, parameters, microhardness, creep

\section{INTRODUCTION}

Technology by galvanic deposition of nickel layers developed intensively over the past decades. Electroplating Nickel is widely used in many engineering applications, from simple thin film coatings for decorative purposes to corrosion, wear and high temperatures.

In many important applications, the nickel layer serves a dual role: to make the decorative aspect of the product surface and provide improved resistance to corrosion or other technical properties depending on the purpose (Šupicová, et al. 2006).

The properties are dependent on surface structure can be strongly influenced by deposition parameters (Bakony et al., 1996).

This paper aims to investigate the influence of technological parameters on the mechanical properties of electrochemical deposition of nickel on copper substrate using a Watts bath by Martens hardness test.

\section{EXPERIMENTAL}

Nickel electrodeposition was carried out in a rectangular cell of size $13.9 \mathrm{~cm}$ x $12.5 \mathrm{~cm}$ x $10 \mathrm{~cm}$ made from Plexiglas, which corresponds to a volume of $1.75 \mathrm{l}$. The cathode [made by 99.98\% purity copper, having the following dimensions (h $x$ L x l): $8.0 \mathrm{~cm}$ x $9.8 \mathrm{~cm}$ x $0.1 \mathrm{~cm}$ ] and the anode [made by $99.7 \%$ purity nickel, having the following dimensions (h x L x l): 10.0 $\mathrm{cm} \times 4.0 \mathrm{~cm} \times 0.3 \mathrm{~cm}$ ] which fitted cell electrolysis was fixed so that cathode surface immersed in the electrolyte must be 0.6 $\mathrm{dm}^{2}$, and the anode $0.25 \mathrm{dm}^{2}$, thus resulting a rate of cathodeanode rate by 2.4 .

The cathode surface was prepared in advance for each electrodeposition experiment, according to the literature procedure (Oniciu \& Grünwald 1980).

The nickel electrolyte of Watts bath type (di Bari 2000) was prepared with following composition: $40.5 \mathrm{~g} / \mathrm{l} \mathrm{NiCl}_{2} \cdot 6 \mathrm{H}_{2} \mathrm{O}$, $292.5 \mathrm{~g} / \mathrm{l} \mathrm{NiSO}_{4} \cdot 6 \mathrm{H}_{2} \mathrm{O}$, 31,5 g/l $\mathrm{H}_{3} \mathrm{BO}_{3}$. All solutions were prepared with bidistilate water. To adjust the $\mathrm{pH}$ of the electrolyte to the following study values $(3.78,5.00,6.21)$ a solution of sodium hydroxide $(\mathrm{NaOH}) 0.1 \mathrm{~N}$ was used.

\begin{tabular}{|c|c|c|c|}
\hline \multirow{2}{*}{$\begin{array}{c}\text { Exp. } \\
\text { No. }\end{array}$} & \multicolumn{3}{|c|}{ Tehnological parameters } \\
\cline { 2 - 4 } & $i\left[\mathrm{~A} / \mathrm{dm}^{2}\right]$ & Temp. $\left[{ }^{\circ} \mathrm{C}\right]$ & $\mathrm{pH}$ \\
\hline 1 & 5 & 45 & 6 \\
\hline 2 & 5 & 45 & 4 \\
\hline 3 & 5 & 15 & 6 \\
\hline 4 & 5 & 15 & 4 \\
\hline 5 & 1,67 & 45 & 6 \\
\hline 6 & 1,67 & 45 & 4 \\
\hline 7 & 1,67 & 15 & 4 \\
\hline 8 & 1,67 & 15 & 6 \\
\hline
\end{tabular}

Tab. 1. Electrodepositing conditions tested

All the electrodeposition experiments were carried out at 2400 Coulombi of electricity by applying current from a from a regulated power supplier $(0$ - $18 \mathrm{~V}, 0$ - $10 \mathrm{~A}$, d.c. power supply GWINSTEK GPR-1810HD). A thermostatic water bath (Lauda E100) was used for maintaining invariable of electrolyte temperature. The $\mathrm{pH}$ of the electrolytes, before starting each experiment with a digital $\mathrm{pH}$ meter (Cole Parmer) was measured. The electrodeposition was carried without stirring of the bath solution. The tested conditions are given in Table 1:

Currently one of the most efficient and rapid methods for characterizing advanced materials in terms of important characteristics is the Martens hardness test. This kind of hardness of a loading-unloading indenter cycle, cycle lasts 120 seconds, can cause a number of important mechanical properties, such as Martens hardness, elastic modulus, mechanical work of elastic deformation, mechanical work of plastic deformation, mechanical work of total deformation, tend to creep, tendency to hardening and the degree of hardening.

The indenter used is a pyramid that leaves a mark on the deposited surface as shown in figure $1 \mathrm{a}, \mathrm{b}$.

Experimental determinations were performed automatically with a Martens hardness, Shimadzu Dynamic Ultra microhardness tester DUH-211S, located in the laboratory for testing and characterization of Food Engineering Faculty of the University "Stefan cel Mare" Suceava.

In this research the mechanical properties of nickel deposits by electrolysis technological parameters were determined following mechanical characteristics (Gutt, 2002):

- Martens Hardness (HM) from the relationship between load and penetration depth under load by the relation:

$$
H M=\frac{F}{26,43 \cdot h^{2}}
$$

where: F- force applied to indenter, $\mathrm{h}$ - depth of penetration under load, in figure $1 \mathrm{~b}$.

$$
\text { - Creep tendency }\left(C_{I T}\right): \quad C_{I T}=\frac{h_{2}-h_{1}}{h_{1}} \cdot 100
$$

- Elasticity modulus of penetration $\left(\mathrm{E}_{\mathrm{IT}}\right)$ was determined by the relationship:

$$
E_{I T}=\frac{1-\left(v_{s}\right)^{2}}{\frac{1}{E_{r}}-\frac{1-\left(v_{i}\right)^{2}}{E_{i}}} \quad E_{r}=\frac{\sqrt{\pi}}{2 C \sqrt{A_{p}}}
$$


All these features are extremely important for material advanced characterization of behavior in the operation of galvanic nickel deposits.

\section{RESULTS AND DISCUSSION}

The surface structure of deposits depends on the number of cristallites formed during the electrolysis and lower ion concentration at the interface electrolyte / layer deposited. Crystallites formation (Figure 1c, d) is strongly affected by technological parameters; which influences the concentration of ions in the cathode layer (Oniciu \& Grünwald, 1980) and Ni electroplating structure influence the mechanical properties.

In figures $2 \mathrm{a}$ and $2 \mathrm{~b}$ are represented pairs of values evolution force (F) - indentation (h) and respectively indentation (h) - time(s), using Martens hardness testing of nickel deposit obtained under different electrolysis technology.

In figures 3 and 4 are represented the mechanical characteristics (Martens hardness (HM), the indentation modulus $\left(\mathrm{E}_{\mathrm{IT}}\right)$, the creep tendency indentation $\left(\mathrm{C}_{\mathrm{IT}}\right)$ and indentation depth) of nickel deposits obtained using Martens hardness testing depending on technological parameters of electrolysis. Also it shows the influence of deposition parameters on mechanical characteristics of covered layers.

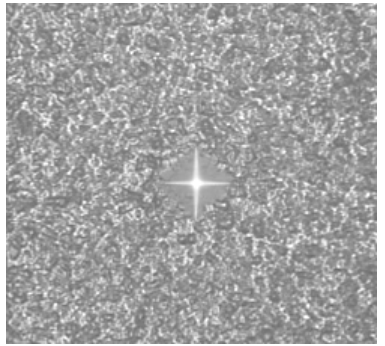

a)

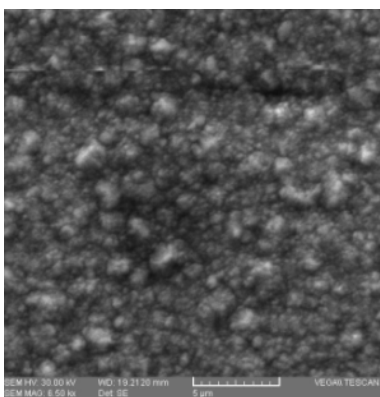

c)

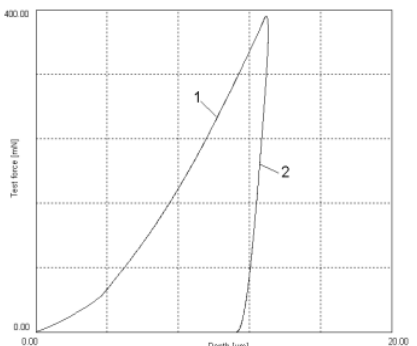

b)

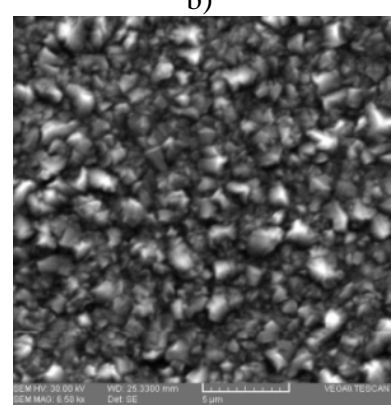

d)
Fig. 1. a) Indenter footprint on nickel deposit b) Graphical representation of the evolution of pairs values, force (F) indentation (h) if the loading process (1) - download (2) to test the Martens hardness of nickel deposit, c) SEM image of exp. no.8, d) SEM image of exp. no.6 (HV $30.00 \mathrm{~kW}, 5 \mu \mathrm{m}$, SE, $6,5 \mathrm{kx})$.

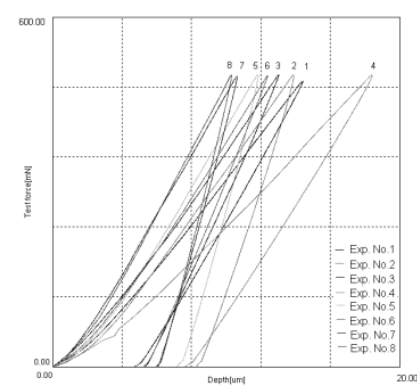

a)

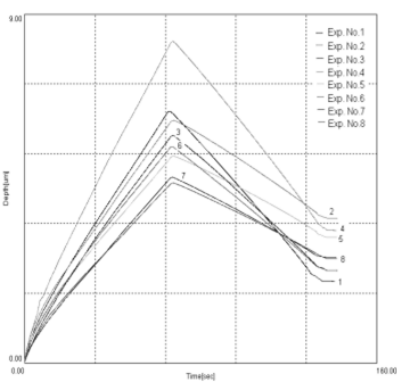

b)
Fig. 2. a) Graphical representation of pair's values evolution, force (F) - indentation (h), using Martens hardness testing of nickel deposit obtained under different electrolysis parameters. b) Graphical representation of pair's values evolution, depth $(\mu \mathrm{m})$ - time (s), using Martens hardness testing of nickel deposit obtained under different electrolysis parameters

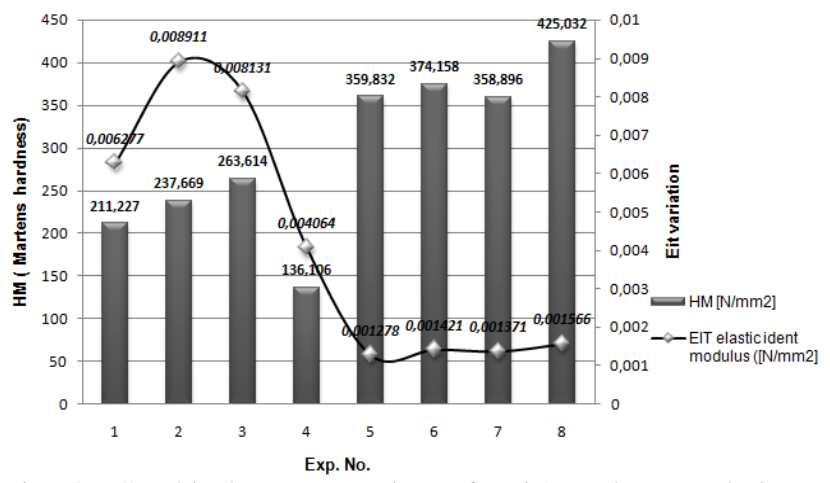

Fig. 3. Graphical representation of pair's values evolution, depth $(\mu \mathrm{m})$ - time (s), using Martens hardness testing of nickel deposit obtained under different electrolysis parameters

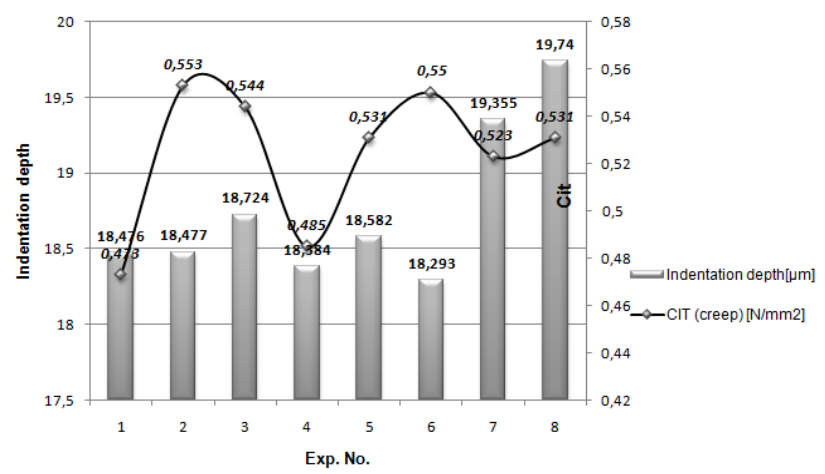

Fig. 4. Graphical representation of pair's values evolution, indentation $(\mu \mathrm{m})$, Cit $\left(\mathrm{N} / \mathrm{mm}^{2}\right)$ using Martens hardness testing of nickel deposit obtained under different electrolysis parameters

\section{CONCLUSIONS}

The influence of technological parameters on the mechanical properties of nickel layers electrodeposited on copper substrates has been studied. The complex influence of current densities, temperature and different bath $\mathrm{pHs}$ on the mechanical characteristics of the deposition layers are compared. Our investigations show that controlled electrodeposition parameters allow tailoring mechanical properties of nichel electrodeposition corresponding to the requirements of the specific technological applications.

This study led to finding a link between electrodeposition parameters and hardness value. These materials are intended to be used in conditions where repeated stress is present.

\section{REFERENCES}

di Bari, G.; (2000). Modern Electroplating, Fourth Edition, Edited by Mordechay Schlesinger and Milan Paunovic (C) 2000 John Wiley \& Sons. Inc, New York

Bakony, I.; Tóth-Kádár, E.; Pogány, L.; Cziráki, Á., Gerőcs, I.; Varga-Josepovits, K.; Arnold, B.; Wetig, K., (1996). Surf. Coat. Tech., 78, 124

Gutt G., (2002). Incercarea si caracterizarea materialelor metalice, Testing and characterization of metallic materials (Roumanian) Editura Tehnică Bucuresti, 260-290.

Oniciu, L.; \& Grünwald, E.; (1980). Galvanotehnica, Electroplating, Editura Ştiinţifică şi Enciclopedică, Bucureşti

Šupicová, M.; Rozik, R.; Trnková, L.; Oriňáková, R.; Gálová, M.; (2006). Influence of boric acid on the electrochemical deposition of Ni, J. Solid State Electrochem., 10, 61-68 